\title{
The Great Divergence: The
}

Death Penalty in the United

States and the Failure of

Abolition in Transatlantic

Perspective

Faculty Research Working Paper Series

\section{Moshik Temkin}

Harvard Kennedy School

\section{July 2015}

\section{RWP15-037}

Visit the HKS Faculty Research Working Paper Series at:

https://research.hks.harvard.edu/publications/workingpapers/Index.aspx

The views expressed in the HKS Faculty Research Working Paper Series are those of the author(s) and do not necessarily reflect those of the John F. Kennedy School of Government or of Harvard University. Faculty Research Working Papers have not undergone formal review and approval. Such papers are included in this series to elicit feedback and to encourage debate on important public policy challenges. Copyright belongs to the author(s). Papers may be downloaded for personal use only. 


\section{Acknowledgments}

This ongoing project is several years in the making. For incisive ideas and exchange I am grateful to the participants in the Radcliffe exploratory seminar Comparative Perspectives on the Death Penalty, held at the Radcliffe Institute for Advanced Study in May 2011, and especially my seminar co-organizer, Carol Steiker of the Harvard Law School. I also warmly thank my former students at the Ecole des Hautes Etudes en Sciences in Paris who took my seminar "La peine de mort aux États-Unis: une perspective transatlantique". Samuel Moyn of the Harvard Law School offered a sensitive critique of this text. I am grateful to audiences at the Complutense University of Madrid, and my host and interlocutor there, José María Puyol. Harvard audiences in Professor Steiker's class on capital punishment, in the History, Culture, and Society Workshop, and at the Center for European Studies, all sharpened my thinking on the topic. My final and most important acknowledgment is to my students and colleagues at the Harvard Kennedy School, who have forced me to think hard and creatively about the connections between history and public policy.

(C) 2015 by Moshik Temkin. All Rights Reserved. 


\section{The Great Divergence:}

The Death Penalty in the United States and the Failure of Abolition in Transatlantic Perspective

How should we explain the persistence of the death penalty in the current day United States? This question-some scholars refer to it as a "puzzle" -has generated ongoing lively discussion among legal scholars, sociologists, political scientists, and historians. In particular, one major challenge facing all students of capital punishment is to explain the striking divide between Europe-where the death penalty has, for all intents and purposes, been formally abolished-and the United States, where, as of this writing, it lives (so to speak). ${ }^{2}$ On the other

\footnotetext{
${ }^{1}$ See, e.g., Franklin Zimring, The Contradictions of Capital Punishment (New York: Oxford University Press, 2003), $i x$
}

${ }^{2}$ As of June 2015, 31 states had the death penalty, 19 did not (along with the District of Columbia). For the sake of comparison, in 2006, 38 states had the death penalty while 12 did not. The seven states to abolish most recently are Connecticut (2012), Maryland (2013), Nebraska (2015), New Jersey (2007), New Mexico (2009), New York (2007), and Illinois (2011). Two of these states still have prisoners on death row, as the abolition was not applied retroactively (New Mexico, Connecticut). As for methods, all executing states use lethal injections; a number of states also allow different methods. Three states allow hangings (Washington, New Hampshire, and Delaware); five states allow the gas chamber (Wyoming, Missouri, Oklahoma, Arizona, California); two states allow firing squads (Utah, Oklahoma); eight states allow electrocution (Virginia, South Carolina, Oklahoma, Kentucky, Tennessee, Arkansas, Alabama, 
hand, it is not entirely clear which is the more striking phenomenon to study. Is it the continued application of the death penalty in the United States, or is it the fact that it no longer exists in Europe? Is the United States "exceptional" in that (as of 2015) it is the only country in the Western, industrialized world, and the only democratic nation (along with Japan and India) to retain capital punishment? Or was the abolition of the death penalty in Europe the more surprising historical development?

In longer-term perspective, the latter development surely demands close analysis. For all of recorded human history, and until fairly recently, across all regions of the world, cultures, and political systems, putting people to death was (and in most of the world continues to be) an acceptable form of punishment. While Europe might be the part of the world most associated with death penalty abolition, in fact the majority of European countries only put an end to this institution in the fairly recent past-for example, Italy in 1949, Germany (formerly West Germany) in 1959, Britain in 1969, and France in 1981. And it is only since the enshrinement of capital punishment's abolition in the treaties that formalized the supra-national authority of the European Union (a process that dates a little over thirty years and entails, among other things, transforming human rights law into binding law) that the absence of the death penalty has become not only a condition for membership in the European community (as well as the Council of Europe) but also a normative European demand from peoples around the world. This rapid

Florida). However, these latter methods are rarely used: from 2001 to 2014, 673 of 683 executions in the United States were carried out by lethal injection. See www.deathpenaltyinfo.org (accessed June 23, 2015) 
European transformation is, in itself, a sea change not only in criminal justice policy, but also in political and philosophical perceptions of the state's relationship with the individual. ${ }^{3}$

In shorter-term perspective, however, the American death penalty can indeed be considered an anomaly. Given the American nation's seemingly natural affiliation with, and historical-cultural connections to, Europe, the United States' attachment to capital punishment strikes many scholars as an outlier in a broader Western story of death penalty abolition. Certainly, the United States keeps some odd company when it comes both to the existence of capital punishment statutes and to the number of people executed-in 2015, the list of top executing countries (in the order of the overall number of executions, not the number of inmates on death row or the rate of executions per capita) was China, Iran, Saudi Arabia, Iraq, United States, Yemen, Pakistan, and North Korea. ${ }^{4}$

While the general public perception might be that the death penalty in the United States has been a national staple, uninterrupted throughout its history, there is one interregnum in the recent history of American capital punishment that foils any attempt at creating a simple

\footnotetext{
${ }^{3}$ There is still no single-volume scholarly global history of capital punishment. For a legal study, see William A. Schabas, The Abolition of the Death Penalty in International Law (New York: Cambridge University Press, 2002)
}

\footnotetext{
${ }^{4}$ http://www.deathpenaltyworldwide.org (accessed June 23, 2015). Researchers often rely on estimates.
} For many countries on the list, the numbers are not made public and executions are shrouded in secrecy. For Capital Punishment around the world, see the exhaustive volume by Roger Hood and Carolyn Hoyle, The Death Penalty: A Worldwide Perspective, Fifth Ed. (Oxford, UK: Oxford University Press, 2015) 
narrative. As of 1968, no execution took place in any state in the union for the next decade. In 1972, the United States Supreme Court, in Furman v. Georgia, placed a moratorium on executions, ruling that the death penalty as had been applied at that time violated the Eighth Amendment's clause on cruel and unusual punishment. ${ }^{5}$ This "abolition", however, was merely temporary. In 1976, following significant public and political backlash that saw rising support for executions, the Supreme Court, in Gregg v. Georgia, changed its mind. ${ }^{6}$ In 1977, Utah became the first state in a decade to conduct an execution-of convicted killer Gary Gilmore, by means of the firing squad. In the following years, the death penalty reemerged as a fixture in American life and a seemingly inextricable part of the justice system. ${ }^{7}$

Yet even if scholars agree that the divergence between the United States and Europe only occurred in the last few decades, how far back in the past do we need to go to locate the origins of this divergence? In this debate, there are two main camps. The first includes scholars who emphasize the connections between state-sponsored executions in the contemporary United States and the nation's distant past. They have focused on such socio-historical factors as the country's colonial heritage, the ethos of the frontier and traditions of vigilante and local justice, the de-centralized structure of the federal state, the unique American mixture of religiosity and politics, and the legacies of slavery, lynchings and other forms of racial violence and

\footnotetext{
${ }^{5}$ Furman v. Georgia 408 U.S. 238 (1972)
}

${ }^{6}$ Gregg v. Georgia 428 U.S. 153 (1976)

${ }^{7}$ For an excellent primer on the topic, see Stuart Banner, The Death Penalty: An American History (Cambridge, Mass.: Harvard University Press, 2002). See also Hugo Adam Bedau, ed., The Death Penalty in America: Current Controversies (New York: Oxford University Press, 1997) 
discrimination, particularly in the American south. Similarly, scholars of capital punishment in Europe trace the origins of the abolition on the continent in a sort of longue durée cultural and intellectual history that emphasizes the legacy of the Enlightenment, the centrality of state-based elites, and the emergence of the idea of the Rights of Man and, later, human rights.

The second camp in this debate emphasizes the contingent dimension of the history of the death penalty, specifically addressing why the death penalty reemerged as a major feature of the criminal justice system in the United States since the late 1970s. These scholars suggest that, until the 1970s, the United States and Western Europe experienced a sort of parallel history of capital punishment. On both sides of the Atlantic the death penalty underwent a very similar trajectory over a period of more than two centuries, including a shift from executions as public spectacles to private procedures during the $19^{\text {th }}$ century and into the $20^{\text {th }}$ century, a peak in state executions in the 1930s, a decline of the institution starting in the 1940s and especially through the 1950s, and a strong trend toward abolition in the 1960s. To the "contingency" side, there is no need for long-term explanations because until about forty years ago there was not much difference between America and Europe when it came to capital punishment. These scholars have focused on the specific factors that brought about the death penalty's permanent abolition in Europe, and its "comeback" in the United States, since the 1970s-the political, legal, and public decision-makers responsible for that divergence, and their reasons for doing so.

This essay reviews and engages some of the most influential and representative scholarship on the death penalty in the United States (and Europe) but proposes a new framework for analyzing its persistence-or abolition-over time. Adopting a comparative framework by focusing on the death penalty in the United States and France-the last and in many ways most significant Western European country to abolish capital punishment-this essay argues 
that the best explanation for the divergence in the practice of the death penalty between the two countries can be found in the very different histories, meanings, and practical applications of abolition, and abolitionism, in the European and American settings.

I agree on the whole with the "contingency" scholars that the period from the 1960s onward deserves particularly close attention and that longer-term "deep cultural" explanations for the divide (to use Carol Steiker's suggestive term) have limited explanatory power when it comes to understanding more recent developments and possibilities for future change. ${ }^{8}$ At the same time, this essay shows that the fundamental differences between conceptions of abolition in the United States and Europe help account for why France, for example, no longer has the death penalty while the United States does. One important part of this story is that in France, abolition was a political, top-down process emanating from part of that country's elite in the face of ongoing public support for executions. Most important, abolition was framed in normative terms, casting executions as a whole (and with no exceptions) as contrary to the principles of human dignity and the foundations of civilized society. In the United States, the movement for abolition (to the extent that it can be defined as a "movement"), beginning in the 1960s, largely ceased to frame its claims in normative terms. It has been primarily a legal (as opposed to political) effort and a procedural (as opposed to moral) cause.

In this context, it is important to look at the precise comparative circumstances and substance of demands for abolition. In France, the debate that led to the permanent abolition of the death penalty took place against the backdrop of some objectively horrific crimes committed

\footnotetext{
${ }^{8}$ See Carol Steiker, “Why We're So Tough on Crime”, Boston Review, October-November 2003 (http://new.bostonreview.net/BR28.5/steiker.html, accesses July 1 2015)
} 
by prisoners condemned to death. In the United States, calls for abolition have revolved primarily around three main issues: the possible (and sometime proven) innocence and/or charisma of some of the more prominent of the condemned, the egregious racial disparities in death penalty sentencing and application, and the brutal methods of executions. These foci have been frequently (though not always) effective at bringing about changes in the application of capital punishment, and a heightened awareness, in some quarters, of its flaws and injustices. But they have not led far when it comes to the goal (such that it exists) of permanent abolition of all forms of capital punishment in all cases.

The permanence of death penalty abolition in Europe (and elsewhere) needs to be understood in the context of the rise of human rights as a dominant political framework and legal paradigm that emerged in the 1940s but gained meaningful traction from the 1970s onward. In the United States, the abolition movement-and the general debate over the death penalty, such that it exists-has not treated the existence of the death penalty as a human rights issue, focusing instead on constitutional and civil rights claims. And so the great divergence between the United States and Europe over the death penalty should be seen in the context of a related, broader divide-whereas in Europe, at least in recent decades, human rights have been a binding legal principal for policymaking and political belonging, in the United States human rights are applied largely for the wider world but not for domestic affairs. The language in which abolition is framed dictates the policy options, and the weakness of the human rights frame for domestic policymaking in the United States (as opposed to its power, at least officially, for law- and policy-making in Europe, and in American foreign policy considerations) has made it difficult to think about abolition in definitive (and not conditional) terms. Abolitionism in recent decades in 
the United States is in fact something of a misnomer, since it has not been about "abolition" in any sense recognizable to Europeans. A more precise term would be "reform".

In other words, this essay looks anew at the "puzzle" of the death penalty's persistence in the United States by shifting the question and arriving at different answers. Rather than asking, "Why does the death penalty still exist in the United States?" this essay starts by asking, "Why has death penalty abolition failed in the United States?" The two questions might appear to be the same but they are actually not. The first can be answered by pointing to the prevalence of the death penalty elsewhere in the world and throughout the past. The death penalty, in the larger scheme of history, is normal. The second question requires a comparison with Europe, with a explicit focus on the more recent past: the process of French abolition took place at the same time as the death penalty returned, in dramatic manner, to America.

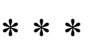

Scholars who have attempted to explain the persistence of the death penalty in the United States by looking at long-term structures and continuities make some compelling points and persuasive arguments. The legal scholar James Whitman has been perhaps the most prominent advocate for the argument that the divide between America and Europe can be explained in longer-term criminal justice practices. In Europe, in his account, this involved the democratization, in a sort of "upward" direction, of the treatment of criminals of different social origins, so that the less fortunate in society were eventually afforded the same protections from excessive punishment as were the more privileged, whereas in the United States the opposite happened-the original distinctions between upper-class and lower-class defendants and convicts 
disappeared over time with the general treatment moving "downward" toward brutal and degrading punishment for all. ${ }^{9}$

Looking at the long-term history of the death penalty in the United States also entails a broader analysis of some of the unique characteristics of American life over time, one of which is the decentralization of law and order. The legal scholar Franklin Zimring has argued that the death penalty in the United States is a study in "contradictions", primarily in that capital punishment gives the state ultimate power over individual lives at the same time that Americans are traditionally resistant to government power. This is why, for the most part, executions are seen as "community justice" and also why opposing the death penalty, rather than being seen as opposition to too much state power, is seen as taking away power from the people. Indeed, for Zimring, one of the remarkable transformations of capital punishment in America is that "[its] proponents... have engineered a symbolic transformation... we now tell ourselves that an executing government is acting in the interest of victims and communities rather than in a display of governmental power and dominance." ${ }^{10}$ While acknowledging that the trans-Atlantic gulf over capital punishment is recent, Zimring explains the ongoing existence of the death penalty in the United States in "the earlier history of nongovernmental violence that was present in many parts of the United States but particularly rampant in the south."11

\footnotetext{
${ }^{9}$ James Whitman, Harsh Justice: Criminal Punishment and the Widening Divide between America and Europe (New York: Oxford University Press, 2003)

${ }^{10}$ Zimring, ix.

${ }^{11}$ Ibid., $x$
} 
The "southern question" in the American death penalty's past and present is crucial in these debates. Much research has shown an uncanny correlation between states-even specific counties-in the American south in which slavery and post-bellum forms of racial discrimination and violence existed in their most intensive and repressive forms, and the prevalence of death sentences and executions handed out in the present day. This continuity is especially pertinent (and disturbing) given that research also shows that in these states in particular (though not exclusively) black men are far more likely than their white counterparts to be sentenced to death, and all the more so when juries are predominantly white. Since the 1970s, Zimring points outand here he is in agreement with several other scholars-the death penalty in the United States has been primarily a southern phenomenon, and thus part of the broader story of race relations in America. ${ }^{12}$

This emphasis on the continuities between old and new south, and the centrality of race, has led some scholars to conclude that future abolition of capital punishment in America entails not much more than targeting very specific constituencies in the southern states, and/or a constitutional edict that would eventually hold southern states to the standards of other states in the union that no longer have the death penalty on their books, thus bringing them in line with

\footnotetext{
${ }^{12}$ See the detailed work on this and related issues by legal scholar James Liebman, including A Broken System, Part II: Why There is So Much Error in Capital Cases, and What Can Be Done About It (Columbia University Law School, 2002), and (with Peter Clarke), “Minority Practice, Majority’s Burden”, Ohio State Journal of Criminal Law 9:1 (Fall 2011), 255-352. On race and capital punishment, a dated but still basic study is David Baldus, George Woodworth, and Charles Pulaski, Equal Justice and the Death Penalty (Boston: Northeastern University Press, 1990)
} 
northern "progress". This interpretation, however, means ignoring a number of complicating factors, including the overall support across the United States for the death penalty, the fact that many non-southern states and most American states still have capital punishment on the books (as of 2015), and the fact that the federal government itself reserves the right, and the prerogative, of putting people to death in capital cases. Treating the south as separate from the north, and the states as separate from each other, and taking the federal government out of the picture, also obfuscates the issue of the death penalty as a national phenomenon with global implications.

Much of this sort of historical interpretation rests on the commonplace notion that the United States, as opposed to European countries, has the qualities of a "weak state", an idea rooted in Alexis de Tocqueville's analysis of early American society. ${ }^{13}$ According to Whitman, this fundamental difference has meant that European elites were able to bring about the abolition of the death penalty in spite of strong public support for executions because in Europe elites are more insulated from democratic pressures, whereas in the United States elites are more dependent on public opinion and thus more prone to demagogic decision-making. As a result, Whitman argues, "a relatively weak state, like the American one, is much more prey to a harsh retributive politics than these [French and German] continental states are, and less able to forbid acts without branding them as evil." ${ }^{, 14}$ According to this analysis, this is why European elites

\footnotetext{
${ }^{13}$ Alexis de Tocqueville, Democracy in America, trans. George Lawrence, ed. J. P. Mayer (New York: Harper Perennial, 1988), 394-5: "The federal government of the United States is tending to get weaker; stage by stage it withdraws from public affairs, continually narrowing its sphere of action. Being naturally weak, it gives up even the appearance of strength."
} 
were able to survive or even thrive politically even after bringing about the end of capital punishment when it was still popular, whereas in the United States-where not only politicians but often also judges and lawyers are accountable to voters-such a move could never happen as long as there is consistent public support for the death penalty, since any elected official calling for abolition would, in many parts of the country, be branded as "soft on crime". 15

The "weak state" thesis is also useful in stressing one major difference between the United States and a European country like France, which is that the American federal political structure gives individual states broad legal and political autonomy, including on the death penalty. This difference is at the root of the assumption of many death penalty scholars that while European abolition occurred via national-level legislation, abolition in the United States could only happen through a longer process of state-by-state abolition, a shift in public opinion in executing states, and an eventual Supreme Court ruling against capital punishment that would impose uniformity and compliance on constitutional grounds.

At the same time, the "weak state" thesis has its limitations. For one thing, as mentioned, the federal government itself has sought (and still seeks) the death penalty, including for crimes

${ }^{14}$ Whitman, Harsh Justice, 201

${ }^{15}$ See also Paul Brace and Brent D. Boyea, "State Public Opinion, the Death Penalty, and the Practice of Electing Judges”, American Journal of Political Science 52:2 (April 2008), 360-372; Stephen B. Bright and Patrick J. Keenan, "Judges and the Politics of Death: Deciding Between the Bill of Rights and the Next Election in Capital Cases”, Boston University Law Review 73 (May 1995), 759-835 
committed in states without the death penalty. ${ }^{16}$ And given that Americans are supposedly suspicious of and resistant to centralized state power, why would many of them be so accepting of the state's authority to kill individual citizens? Zimring's view that the death penalty has become a misleading representation of the people's will, rather than of state power-one component of his account of "contradictions"-is a partial explanation. But it seems more plausible that Americans are historically more ambivalent about state power than scholars such as Whitman and Zimring might account for. On certain issues-health care, education, the economy, and religion come to mind-the "weak state" thesis might ring true. In other respects, it is perhaps less pertinent. In the domains of national security and of law and order, for instance, history suggests that Americans have been more accepting, indeed even embracing and celebratory, of a strong state-and sometimes also of a repressive state. The idea that Americans might naturally gravitate toward an opposition to the capital punishment because of their fear of the state is less convincing in that light. A case could be made that Americans' support for the

${ }^{16}$ Most recently, the federal government sought, and obtained, a death sentence for the 2013 Boston Marathon Bomber Dzokhar Tsarnaev, in a state (Massachusetts) that abolished the death penalty in 1984, has not executed anyone since 1948, and in which the overwhelming majority of the public opposes capital punishment. See Katharine Q. Seelye et al, "Death Sentence for Boston Bomber, Dzokhar Tsarnaev, Unsettles City He Tore Apart”, New York Times May 162015 (http://www.nytimes.com/2015/05/17/us/death-sentence-for-boston-bomber-dzhokhar-tsarnaev-unsettlescity-he-tore-apart.html, accessed July 12015$)$. The history of federal capital punishment has been a minor topic among death penalty scholars and deserves more attention. For a legal study, see Rory K. Little, "The Federal Death Penalty: History and Some Thoughts About the Department of Justice's Role", Fordham Urban Law Journal 26 (1998-1999), 346-508 
death penalty is also a support for the state itself doling out punishment, along with a belief that executions represent the democratic will. ${ }^{17}$

Like Whitman and Zimring, the legal scholar and sociologist David Garland has examined the history of the death penalty in the United States in the context of criminal justice practices in the longue durée, with a comparative look at Europe, and he has also grappled with the "weak state" factor, though his conclusions are somewhat different. In a seminal recent work, Garland takes the so-called culturalist (not his term) explanations to task, emphasizing the contingent element of the death penalty's persistence in the United States in what can be called a Western "age of abolition". He offers a sophisticated socio-cultural analysis of his own of American capital punishment that portrays it as out of step in many ways with the modern world. He differs with Whitman and Zimring not so much over the use of culture as a mode of analysis but rather over what he sees as a particular kind of analysis that supposedly treats culture as unchanging. ${ }^{18}$

${ }^{17}$ See William J. Novak, “The Myth of the 'Weak' American State”, American Historical Review 113:3 (June 2008), 752-772, and the subsequent “ $A H R$ Exchange: On the 'Myth' of the 'Weak' American State", American Historical Review 115:3 (June 2010), 766-800, with contributions from John Fabian Witt, Gary Gerstle, and Julia Adams.

${ }^{18}$ David Garland, Peculiar Institution: America's Death Penalty in an Age of Abolition (Cambridge, Mass.: Harvard University Press), 2010. See also Garland's extensive previous work on the topic, especially The Culture of Control: Crime and the Social Order in Contemporary Society (Chicago: The University of Chicago Press, 2001) 
Garland points out that executions in America are rare compared with the actual number of convicts on death row, and that appeals processes are interminably long, facts that he takes as a sign of a national "ambivalence" regarding the death penalty. Like Zimring, Garland believes that many Americans-even those who support capital punishment-are deeply uncomfortable with how this "peculiar institution" functions. Institutions are conflicted about it, the higher courts treat it gingerly, and elites understand that it is outmoded. It has been a source of discomfort and embarrassment for the United States on the global stage for three decades at least. So why has it persisted? Garland argues that the death penalty has retained power as a cultural currency of sorts-the public is titillated by the use of a punishment that appears out of date and taboo; executions provide the public with "a release from repression". ${ }^{19}$ (Some of the other terms Garland uses in this context include "lascivious enjoyment" and "pornography of pain and death".) Politicians trumpet their support for capital punishment so as to brandish their tough-oncrime credentials and commitment to states' rights. In the end, to explain why the United States diverged from Europe on what appeared to be a common path to abolition, he resorts to explanations that are not too far from Zimring's and Whitman's, stressing the three following factors: the weakness of the American state, the legacies of slavery and lynchings, and religiosity. And, similarly to Zimring, Garland implies that capital punishment's days in the United States are numbered: the institution will eventually crumble under the weight of its own internal contradictions and external abnormality. ${ }^{20}$

${ }^{19}$ Garland, Peculiar Institution, 304 
Perhaps because they study the death penalty in the United States in the context of criminal justice policy (albeit in different ways), and because the general direction of criminal justice in much the rest of the Western world has moved in the opposite direction, Garland, Zimring, and Whitman-along with several other scholars-treat the persistence of the death penalty in the United States as an extraordinary phenomenon that requires profound cultural and psychological explanation. ${ }^{21}$ But what if the reasons for capital punishment's survival are to be found not in the depths of American society but at its surface? If Whitman is at one end of the culture versus contingency debate (with Zimring and Garland occupying a sort of middle ground), at the other end is Carol Steiker, who has written extensively and astutely (often with her brother and collaborator Jordan Steiker), about the death penalty in the United States, most

${ }^{20}$ See also Garland, "Modes of Capital Punishment: The Death Penalty in Historical Perspective", in Garland, Randall McGowen, and Michael Meranze, eds., America's Death Penalty: Between Past and Present (New York: New York University Press, 2011), 30-71

${ }^{21}$ Other studies that situate the American death penalty in the context of criminal justice policy include Michael Tonry, "Explanations of American Punishment Policies: A National History”, Punishment and Society 11:3 (July 2009), 377-394; Nicola Lacey, The Prisoners' Dilemma: Political Economy and Punishment in Contemporary Democracies (New York: Cambridge University Press, 2008); William J. Stuntz, The Collapse of American Criminal Justice (Cambridge, Mass.: Harvard University Press, 2011); Marie Gottschalk, The Prison and the Gallows: The Politics of Mass Incarceration in America (New York: Cambridge University Press, 2006) 
specifically the role of the courts. In a sharp review of Garland's book that doubled as a lively exercise in counterfactual legal history, Steiker suggested that the ongoing existence of the death penalty of the United States is due to a number of Supreme Court decisions in the last halfcentury that could have gone the other way and, more than any deeper cultural or sociological factors, are what separated the United States from Europe. "The nature and timing of the Court's intervention in the country's capital punishment drama played a crucial role in the contemporary form of the death penalty", she writes. "Moreover, [it] diverted the United States from the path of human rights discourse embraced in Europe.",22

Steiker's series of counterfactuals begins in the 1960s, when death penalty abolitionism in the United States was in its zenith. From the late 1950s to the mid-1960s, support for capital punishment fell to an all-time low in the United States (for reasons to be discussed below), and in 1966, for the first (and last) time, opinion polls showed a slim majority of the public against it.

${ }^{22}$ Carol Steiker, “Capital Punishment and Contingency”, Harvard Law Review 125:3 (January 2012), 777. Steiker's extensive work on the death penalty includes, e.g., "A Tale of Two Nations:

Implementation of the Death Penalty in 'Executing' Versus 'Symbolic' States in the United States" (with Jordan Steiker), Texas Law Review 84:7 (June 2006), 1869-1927; "Seduction of Innocence: The Attraction and Limitations of the Focus on Innocence in Capital Punishment Law and Advocacy" (with Jordan Steiker) Journal of Criminal Law \& Criminology 95:2 (Winter 2005), 587-624; “No, Capital Punishment is Not Morally Required: Deterrence, Deontology, and the Death Penalty" Stanford Law Review 58:3 (December 2005), 751-789; “Capital Punishment and American Exceptionalism” in Michael Ignatieff, ed., American Exceptionalism and Human Rights (Princeton, N.J.: Princeton University Press, 2005), 57-89 
The U.S. Supreme Court, led by Chief Justice Earl Warren, liberalized many criminal justice procedures, but left the death penalty itself aside. This, to Steiker, was the Court's biggest missed opportunity: "if the Court addressed the ultimate constitutionality of capital punishment in the mid-1960s... it is entire possible that the Court could and would have acted definitively [toward abolition].".23

All this was occurring in a global context: in 1965, British parliament passed an act to abolish the death penalty provisionally, and this became permanent in $1969 .{ }^{24}$ For many observers at the time, the United States appeared to be moving in the same abolitionist directionindeed, in the early 1960s it looked to be ahead of the curve-but the Court's failure to act on this zeitgeist and on its own liberal proclivities earns Steiker's lament that "if the Warren Court had produced an enduring constitutional abolition of capital punishment in the 1960s, the United States would have been at the forefront of the wave of abolition that swept Europe from the 1970s to the 1990s, and the U.S. would have received (or at least assigned itself) credit for being

${ }^{23}$ Steiker, "Capital Punishment and Contingency," 778

${ }^{24}$ For the British death penalty and abolition, see, e.g., Brian P. Block and John Hostettler, Hanging in the Balance: A History of Capital Punishment in Britain (Winchester, UK: Waterside Press, 1997); Randall McGowen, "History, Culture, and the Death Penalty: The British Debates, 1840-70", Historical Reflections/Reflexions Historiques 29:2 (Summer 2003), 229-250; V. A. C. Gatrell, The Hanging Tree: Execution and the English People, 1770-1868 (New York: Oxford University Press, 1994); Peter Linebaugh, The London Hanged: Crime and Civil Society in the Eighteenth Century (New York: Cambridge University Press, 1992) 
a leader in this human rights revolution, a position that would have made backsliding more unattractive, just as it has in Europe."25

Steiker's second counterfactual is no less intriguing. Suppose, she suggests, that the Supreme Court had not intervened in the death penalty issue in 1972. Without the Furman decision, there would not be the backlash that led to the Court's Gregg decision of 1976 and the subsequent growth of capital punishment to juggernaut proportions. Perhaps the death penalty might have declined and petered out on its own, without a Court decision that antagonized southern states and their populist, tough-on-crime politicians and constituents. Steiker's last "road not taken" counterfactual is based on a close call: In 1987, in McCleskey v. Kemp, the Supreme Court voted 5-4 to reject a challenge to the constitutionality of the death penalty based on its racially discriminatory pattern of imposition. The deciding vote was that of Justice Lewis Powell, who wrote the majority opinion-and later stated that he regretted his vote and the decision of the Court. ${ }^{26}$

${ }^{25}$ Steiker, ibid., 781

${ }^{26}$ Ibid., 784-6. McCleskey v. Kemp 481 U.S. 279 (1987). For background, see Randall Kennedy, “McCleskey v. Kemp: Race, Capital Punishment, and the Supreme Court”, Harvard Law Review 101:7 (May 1988), 1388-1443. Powell is not the only Supreme Court Justice to regret, once off the bench, his former support of capital punishment. Former Justice John Paul Stevens, who was nominated to the Court by Republican President Gerald Ford in 1975 and eventually became a leader of the Court's so-called liberal wing, upheld the death penalty for the 35 years he served on the Court, yet has become a vocal opponent of executions since his retirement in 2010-when he can no longer make a difference. See Stevens, “On the Death Penalty”, New York Review of Books, Dec. 232010 (http://www.nybooks.com/articles/archives/2010/dec/23/death-sentence/, accessed July 1 2015), a review 
The main critique one can make of Steiker does not concern her specific argument necessarily, but rather the nature of all counterfactual history. Her keywords are if, could have, and would have. But the things that could have happened did not happen. The primary role of the historian is to explain what did happen, and in this case what did happen paints a more pessimistic picture than does Steiker's alternative scenario. All Supreme Court decisions are inherently temporary, based on Constitutional interpretation through a particular political frame and temporal context. And, as with all counterfactual history, it is impossible to know what would have happened subsequently had one prior thing happened differently-for example, what might have transpired in the long run if the Supreme Court decided in the 1960s that capital punishment was unconstitutional. The sort of reaction that met Furman could have occurred anyway-there is reason to believe that the anti-liberal backlash of the Nixon era would have included the return of the death penalty. The President himself was a supporter of the death penalty for certain crimes and was not shy about saying so immediately after a Supreme Court decision to the contrary. ${ }^{27}$

Similarly, it makes sense to conclude that, had the Supreme Court ruled against the death penalty in 1987, the national hysteria over violent crime that marked that period would have eventually led states to push once again for the right to execute, and an increasingly conservative of Garland's Peculiar Institution, and Andrew Cohen, "Now He Tells Us: John Paul Stevens Wants to Abolish the Death Penalty", The Atlantic April 72015

(http://www.theatlantic.com/national/archive/2014/04/now-he-tells-us-john-paul-stevens-wants-toabolish-the-death-penalty/359851/, accessed July 12015$)$

${ }^{27}$ William Robbins, “Nixon Backs Death Penalty for Kidnapping, Hijacking”, New York Times June 30, 1971, 1 
Supreme Court to grant them their wish. After all, just one year after McCleskey, Governor Michael Dukakis of Massachusetts lost a presidential election in large part because he said in a nationally televised debate that he was against the death penalty (in calm response to a lurid question about how he'd feel if his own wife were raped and killed), enabling his opponent to portray him as weak on crime. In sum, there is no reason to believe that abolition of capital punishment by the Supreme Court, whether in the 1960s or the 1980s, would have been any more permanent than the non-permanent abolition of 1972. The Court has been known to change its mind, including about the death penalty, depending on its political mood and reading of changing public winds. More recently, the Court struck down the core elements of one major legislative piece of the civil rights era-the Voting Rights Act of 1965-that many observers considered untouchable. ${ }^{28}$

It is quite true that the Supreme Court has been a central actor in the drama of American capital punishment. Since the 1960s, as the Steikers show, it has engaged in what might be called a project of constitutional oversight of capital punishment, essentially trying to get it rightcountering it when its procedures became constitutionally intolerable in the Court's view, reinstating it when it seemed to have fixed itself in the eyes of public opinion and state-level actors. In the Steikers's view, this constitutional oversight might lead to the death penalty's abolition at the hands of the Court in the foreseeable future. ${ }^{29}$

\footnotetext{
${ }^{28}$ Adam Liptak, "Supreme Court Invalidates Key Part of Voting Rights Act”, New York Times June 23, 2013,1
} 
At the same time, because the Court's examination of the death penalty has been mostly procedural, one could argue that the Court's centrality in the death penalty story is not in a direct engagement with the implications of capital punishment but rather in its reluctance to confront them head-on. As the legal scholar Andrew Hammel recently pointed out, the Court has, "over the span of decades, obscured the fundamental normative questions raised by capital punishment in the United States." Hammel concluded that the Court "no longer has the will or desire" (if it ever did, it should be added) to declare the death penalty unconstitutional. It has, he claims, "disarmed". ${ }^{30}$ Similarly, Zimring has argued that since the 1980 s the Supreme Court has gradually distanced itself from the death penalty, sending most cases back to the states-a phenomenon that one scholar once called "deregulating death."31 The Court, Zimring wrote in 2001, "remains the primary architect of the constitutional law of capital punishment, but most of the justices on the court have no enthusiasm for law making in capital cases."32

${ }^{29}$ Carol Steiker, "Unpremeditated: Capital Punishment and American Law", Lecture at Radcliffe Institute of Advanced Study, April 22, 2015 (video available at https://www.radcliffe.harvard.edu/video/carol-ssteiker-capital-punishment-and-american-law, accessed July 12015 ), and her co-written study with Jordan Steiker, forthcoming from Harvard University Press.

${ }^{30}$ Andrew Hammel, Ending the Death Penalty: the European Experience in Global Perspective (New York: Palgrave MacMillan, 2010), 226-9

${ }^{31}$ Robert Weisberg, "Deregulating Death”, The Supreme Court Review (1983), 305-95

${ }^{32}$ Zimring, ibid., 10. Of the Supreme Court Justices in 2001, five remain in 2015: Antonin Scalia, Anthony Kennedy, Stephen Breyer, Ruth Bader Ginsburg, Clarence Thomas. For an earlier argument 
In general, the focus on the Supreme Court as the main actor in the death penalty story, and on the Constitution as the main frame within which to debate it, risks our losing sight of other important factors that determine capital punishment's fate in the United States. Indeed, this can be one main limitation of examining the death penalty as part of the topic of criminal justice generally: it fails to capture a powerful aspect of the death penalty that sets it apart from other

forms of severe punishment and important issues such as mass incarceration. That aspect of capital punishment-we might call it finality-is tricky for historians and social scientists: it concerns life and death and existential questions of morality. But the death penalty, when it exists and when it is abolished, is always ultimately about these things. Treating capital punishment as primarily an issue of law, specifically criminal justice, also fails to fully grapple with its political dimensions-what governments do about it, how what they do relates to public opinion, and to what extent political structures and leadership dictate any particular polity's death penalty trajectory. As we will see, one main difference between the history of death penalty abolition in France and the history of abolition (or the lack thereof) in the United States is between the centrality of national political leadership in the French case, and its relative absence in the American case.

The death penalty in the colonial-era and post-revolutionary United States, as well as in pre- and post-revolutionary France, was a natural extension of a universally accepted form of

against the Supreme Court's authorization of executions, see Raoul Berger, Death Penalties: The Supreme Court's Obstacle Course (Cambridge, Mass.: Harvard University Press, 1982) 
punishment that, for all recorded human history across the globe, was taken for granted. There were, to be sure, considerable shifts in the ways (and the extent to which) the death penalty was applied in Europe, and the colonial world, in the modern era. According to Garland, during the late $15^{\text {th }}$ and $16^{\text {th }}$ century-an epoch noted for the first major centralization of European states around dominant monarchies-capital punishment increased in scope, characterized by gruesomely inventive public displays meant to project absolute power to a terrified, subservient people. The range of crimes eligible for execution was of near-biblical proportions, with the most severe punishments reserved for crimes against the established political, social, familial, and religious order. Over the course of the $18^{\text {th }}$ century the use of the death penalty went into relative decline, a process that continued from that point on (some of the reasons Garland cites include the increasing legitimacy of states and the rise of the penitentiary and imprisonment as an alternative to executions), and historians agree that the $19^{\text {th }}$ century saw the transformation of capital punishment into the institution that is recognizable in recent times. ${ }^{33}$

In his study of European death penalty abolition, Hammel describes the $19^{\text {th }}$ century changes as taking place in three progressive modes: restricting capital punishment to only "serious" crimes (e.g., murder and not petty theft), transforming executions from public spectacles with a strong religious component into private, legalized ceremonies within prison

${ }^{33}$ Garland, Peculiar Institution, 70-126 
walls, and introducing execution techniques that were considered more "humane" or modern. ${ }^{34}$ These transitions reflected the changing nature of political power and criminal justice, as well as the development of more sophisticated forms of government. ${ }^{35}$

Building on the insights of social and political theorists from Norbert Elias to Michel Foucault, a number of scholars of the death penalty have seen this period of transformation as marked by the state's will to "civilize", to control the population through more sophisticated and indirect means, and simultaneously to increase its own power and legitimacy. ${ }^{36}$ By the start of

${ }^{34}$ See, e.g., Jürgen Martschukat, “'The Art of Killing by Electricity’: The Sublime and the Electric Chair", Journal of American History 89:3 (December 2002), 900-921; Richard Moran, Executioner's Current: Thomas Edison, George Westinghouse, and the Invention of the Electric Chair (New York: Vintage, 2003); Gilbert King, The Execution of Willie Francis: Race, Murder, and the Search for Justice in the American South (New York: Basic Civitas, 2008)

${ }^{35}$ Hammel, 18-21; for background, see especially Garland, "Modes of Capital Punishment”, 49-58

${ }^{36}$ On this point see especially Garland, ibid., and Meranze, "Michel Foucault, the Death Penalty, and the Crisis of Historical Understanding”, Historical Reflections/Reflexions Historiques, op. cit., 191-210. See Michel Foucault, Discipline and Punish: The Birth of the Prison (New York: Vintage, 1995; originally published as Surveiller et punir: Naissance de la prison, Paris: Gallimard, 1975), and Norbert Elias, The Civilizing Process: Sociogenetic and Psychogenetic Investigations (Oxford, UK: Blackwell, 2000). For an illuminating study of these transformations in France see Paul Friedland, Seeing Justice Done: The Age of Spectacular Capital Punishment in France (Oxford, UK: Oxford University Press, 2002). For an 
the $20^{\text {th }}$ century, the death penalty as an institution had completed its transformation from a state tool designed to instill fear and control into a legal instrument that complemented the bureaucratic, centralized state with its police force, justice system, and prisons-as well as more liberal, democratic tendencies (sometimes and in some places), taxation, citizenship, and increased (though still limited) political representation. As Garland put it, "the modern death penalty was no longer an unquestionable expression of sovereign power but a policy tool like any other. If it was deployed, in the face of ideological doubts, it was because it was seen to serve human purposes: to deter crime, save innocent lives, inflict pain with a view to creating benefits. ${ }^{37}$

In attempting to understand how the death penalty as a transatlantic phenomenon transitioned from its "parallel" mode to the great divergence of the later $20^{\text {th }}$ century, perhaps a useful place to start a comparative account is the 1920s, when the Sacco-Vanzetti affair shook world public opinion. Nicola Sacco and Bartolomeo Vanzetti, two Italian immigrants and anarchists convicted and sentenced to death in Massachusetts for the 1920 robbery and murder of a factory paymaster and his guard, were executed in 1927. Both men were (and are) widely considered to be innocents, railroaded by a hostile legal system due to their radical politics and ethnic and social origins. The lead-up to, and aftermath, of their executions (by electrocution) was the occasion of a boisterous national debate and violent global protest. In the United States, Europe, Latin America, North Africa, and East Asia, demonstrators clashed with police, rioters

equivalent transformation of Spanish penal law, see José María Puyol Montero, "La abolicion de la pena de horca en España", Cuadernos de historia del derecho 4 (1997), 91-140

${ }^{37}$ Garland, "Modes of Capital Punishment", 51 
destroyed property, intellectuals signed petitions, political leaders made speeches, public figures appealed for the two men's lives, and diplomats strove to find a compromise, to no avail. Sacco and Vanzetti were executed to a chorus of condemnation, although many Americans, not surprisingly, supported the verdict-whether or not the pair was actually guilty of the crime. ${ }^{38}$

There were several compelling reasons for the protest, including the six-year wait between their conviction and their execution; nowadays, in death rows in America, that length of time might seem quaint, but many then considered it to be particularly cruel and unusual treatment. Sacco and Vanzetti eloquently and forcefully maintained their innocence and developed reputations as thoughtful, principled men. Their trial was deeply flawed and the evidence against them was weak. There were also broader claims around the world, especially in Europe, against the United States as a whole, seen by many as an intolerant society that was taking out its frustrations and fears on hapless immigrants and radicals; and many American intellectuals panned the state of Massachusetts, which they saw as a retrograde place determined to punish foreigners in its midst.

What was missing from all this anger and remonstration was a principled, organized, broad opposition to the institution of the death penalty itself. That was not the European complaint. To the degree that there was opposition to the execution-and there was, though not really in the mainstream-it existed in both in the United States and Europe. France, the country in which the most widespread protest took place, also had the death penalty, so it would not

\footnotetext{
${ }^{38}$ For the Sacco-Vanzetti case, see Bruce Watson, Sacco and Vanzetti: The Men, the Murders, and the Judgment of Mankind (New York: Viking, 2007); Moshik Temkin, The Sacco-Vanzetti Affair: America on Trial (New Haven, Conn.: Yale University Press, 2011)
} 
make sense for its citizens to criticize Massachusetts on that score. The Sacco-Vanzetti case reveals that, despite all the mutual hostility between the United States and Europe that it created, there was no divide over the death penalty itself.

One of the more ironic legacies of the Sacco-Vanzetti affair was that gave a boost to the anti-death penalty movement in the United States, which since the $18^{\text {th }}$ century experienced several ups and downs, as we shall see. ${ }^{39}$ In particular, it made an enormous impact on the latterday history of the American death penalty by featuring the sort of defendants that would star in abolitionist campaigns down the road: charismatic, eloquent, probably innocent, victims of a flawed judicial procedure, and members of a victimized and downtrodden minority. But in the 1920s-and into the 1950s-the death penalty was not up for major debate. The 1930 s were the high peak of executions in the United States and much of Europe, though the political and social contexts were different: In the United States, the hardships of the Great Depression led to a rise in crime (real or alleged), which in turn led to increased use of the death penalty. In particular, as Austin Sarat and other scholars have shown, the relative decline in improvised lynchings of black men in the south was replaced by nominally legal state executions, disproportionately targeting blacks-a pattern that continues to the present. ${ }^{40}$ In much of Europe the Depression had

\footnotetext{
${ }^{39}$ For the Sacco-Vanzetti case and the death penalty in Massachusetts, see Alan Rogers, Murder and the
} Death Penalty in Massachusetts (Amherst, Mass.: The University of Massachusetts Press, 2008, chapter 6 (“Sacco and Vanzetti”)

\footnotetext{
${ }^{40}$ Austin Sarat and Charles Ogletree, Jr., eds, From Lynch Mobs to the Killing State: Race and the Death Penalty in America (New York: New York University Press, 2006); see also Michael J. Pfeiffer, Rough Justice: Lynching and American Society, 1874-1947 (Urbana, Ill.: University of Illionois Press, 2004) and
} 
similar effects, and the rise of fascist parties to power in several countries also ramped up the use of capital punishment for offenses of a political nature. ${ }^{41}$

The late 1940s and 1950s saw a transatlantic turning away from the death penalty. In the aftermath of World War II, Europe and the United States looked very different from each other (and from what each looked like before the war), but one thing they had in common was a backlash to the death penalty that had a lot to do with a general revulsion from the horrific violence of the prior decade. Italy and West Germany, the former fascist states, were the first to abolish executions in civil cases. As Garland has cogently argued, in a postwar Western world that saw the rise of liberalism, democracy and various iterations of the welfare state, capital punishment came to be seen-particularly by elites-as increasingly out-of-place and outmoded, a relic from darker days. ${ }^{42}$

To be sure, there were drastic variations in this overall trajectory. While many European countries embraced some forms of social democracy and the welfare state (Britain, France, West Germany, Italy), others retained or fell to authoritarian governments (Spain, Greece, Portugal, and the countries of the Soviet-controlled Eastern Bloc), and the former were faster to move toward death penalty abolition. Across the Atlantic, the political circumstances were different in many ways; as Garland puts it, "the United States sustained its longstanding commitment to

Margaret Vandiver, Lethal Punishment: Lynchings and Legal Executions in the South (New Brunswick, NJ: Rutgers University Press, 2006)

${ }^{41}$ For Nazi Germany, see Richard Evans, Rituals of Retribution: Capital Punishment in Germany, 16001987 (New York: Oxford University Press, 1996), chs. 13-16

${ }^{42}$ See Garland, ibid.; Hammel, ibid. 
radical local democracy, devolving most social and penal policy to local political actors-an arrangement that fostered local variation and populist politics rather than uniform national governance by professional elites." ${ }^{43}$ It was this difference that would soon propel the death penalty in Europe and the United States in opposite directions. While Britain, for example, abolished the death penalty through legislation, the United States was not in a position to do so. Still, in the 1950s and early 1960s, one powerful commonality overshadowed the many differences: both American and European elites, and to a lesser extent general public opinion, became increasingly abolitionist. The death penalty seemed to many to be on its way out on both sides of the Atlantic. Public intellectuals who saw the death penalty as the major moral issue of the day included Arthur Koestler (Reflections on Hanging, 1957) and Albert Camus (Reflections on the Guillotine, 1960). These works isolated the death penalty from other parts of criminal justice policy, treating it as a matter of national shame and calling for its abolition as principled rejection of a barbaric past. ${ }^{44}$

As Hammel explains, while the push for abolition was always an elite phenomenon in both Europe and the United States, the institutional filters between the public climate and legal practice are completely different in both places, so that "the European filter... insulates the

${ }^{43}$ Garland, "Modes of Capital Punishment", 59

${ }^{44}$ Arthur Koestler, Reflections on Hanging (New York: Macmillan, 1957); Albert Camus, Reflections on the Guillotine: An Essay on Capital Punishment (Michigan City, Ind.: Fridtjof-Karla Publications, 1960). See also Koestler, Hanged by the Neck: An Exposure of Capital Punishment in England (Baltimore: Penguin Books, 1961) 
process of penal policy formation from the public's will, whereas the American filter permits, and even requires, criminal justice policy to be acutely responsive to public opinion. ${ }^{245}$ This was not so much of an issue, or transatlantic divide, in the early to mid-1960s, for example, when crime rates were down and public support for capital punishment was in decline on both sides of the Atlantic. But it did become a significant factor in the late 1960s and beyond, when abolitionists in Europe were able to push through their goals in the face of a much less favorable public opinion, whereas in the United States, as crime rates began to climb in the late 1960s and public opinion began once again to support capital punishment, policymakers and legal authorities felt obligated to respond to the changing winds. Indeed, while there might be a popular conception that Europeans were quicker and earlier to arrive at an abolitionist position than Americans, the history of the death penalty in these years confounds our preconceptions. Even when support for the death penalty was in decline in the United States, in West Germany and Britain they remained relatively higher. In 1969, the year Britain abolished capital punishment, polls showed that 85 percent of the public was "somewhat" or "strongly" in favor of retaining the death penalty, this at a time when public opinion in the United States was much closer to 50-50 and yet abolition did not happen. ${ }^{46}$

${ }^{45}$ Hammel, 16

${ }^{46}$ Hammel, 13. On capital punishment and public opinion see, e.g., David Jacobs and Stephanie L. Kent, “The Determinants of Executions Since 1951: How Politics, Protests, Public Opinion, and Social Divisions Shape Capital Punishment”, Social Problems 54:3 (2007), 297-318; Phoebe Ellsworth and Lee Ross, "Public Opinion and Capital Punishment: A Close Examination of the Views of Abolitionists and Retentionists”, Crime and Delinquency 29 (January 1983), 116-69; Tom Tyler and Renee Weber, “Support for the Death Penalty: Instrumental Response to Crime, or Symbolic Attitude?”, Law and 
The principal catalyst in the United States in the 1950s and early 1960s for the turn away from the death penalty was the rise of what the historian Michael Meranze has called the "rehabilitationist regime". ${ }^{47}$ Legal authorities and policymakers increasingly championed the idea that criminals could change for the better and, under the wise guidance of benevolent liberal institutions and experts, be reeducated or even reintegrated into society. This rehabilitationist ideal drew on a wave of scholarship in the social sciences that reflected a growing optimism in this period regarding the nature and origins of crime. Criminologists and psychologists promoted the idea that the path to crime was paved primarily by social and economic factors, including poverty, lack of education, and proper socialization, and not by any innate criminality. Bolstered also by the decline in crime rates in the wake of the postwar economic boom, many liberal elites now considered the death penalty, as the prominent criminologist Thorsten Sellin put it in his

Society Review 17:1 (Nov. 1982), 21-46; James Fox, Julie Bonsteel, and Michael Radelet, "Death Penalty Opinion in the Post-Furman Years", New York University Review of Law and Social Change 18 (19901991), 499-528; Christopher Z. Mooney and Mei-Hsien Lee, "The Influence of Values on Consensus and Contentious Morality Policy, 1956-82”, Journal of Politics 62:1 (February 2000), 223-39

\footnotetext{
${ }^{47}$ Meranze, "Michel Foucault, the Death Penalty, and the Crisis of Historical Understanding”, op. cit.
} 
1967 essay "The Inevitable End of Capital Punishment", "an archaic custom of primitive origin., ${ }^{48}$

A series of death row inmates of that era served as rallying points for this new way of thinking. Two of these cases were in Illinois: Nathan Leopold and Paul Crump. Leopold, one half of the infamous Leopold-Loeb duo of young thrill killers convicted in 1924 for the murder of a neighbor boy in Chicago, had been saved from a death sentence by the courtroom brio of famed attorney Clarence Darrow. By the 1950s, Leopold had established his reputation as a redeemed, model prisoner, thanks in large part to the publication of his memoir, Life Plus 99 Years (1958). He was paroled that year and soon moved to Puerto Rico, where he became a medical researcher and ornithologist. ${ }^{49}$ Crump was sentenced to death for killing a security guard during an armed robbery in Chicago, in 1953. In 1962, Crump, an African-American, published a well-received autobiographical novel, Burn, Killer, Burn!, featuring a blurb by the author James Baldwin. No one doubted Crump's guilt, but given the circumstances of his trial (he was the only one of five robbers to be sentenced to death) and the widespread belief that he was fully rehabilitated, Illinois Governor Otto Kerner commuted his sentence to life in prison. ${ }^{50}$ Another highly publicized case featured in Truman Capote's 1966 non-fiction novel In Cold Blood, which

${ }^{48}$ Quoted in Hammel, 201. This is the last chapter in Thorsten Sellin, ed., Capital Punishment (New York: Harper \& Row, 1967)

${ }^{49}$ Nathan F. Leopold, Life Plus 99 Years (Garden City, NY: Doubleday, 1968). For a broader perspective, see Paula Fass, "Making and Remaking an Event: The Leopold and Loeb Case in American Culture", Journal of American History 80:3 (Dec. 1993), 919-951

${ }^{50}$ Paul Crump, Burn, Killer, Burn! (Chicago: Johnson Pub. Co., 1962) 
helped humanize two men, Richard Hickock and Perry Smith, hanged in Kansas in 1965 for the brutal murder of a farming family during a home invasion. ${ }^{51}$

Perhaps the most celebrated case of all, and the one that best captured this rehabilitationist mood, was that of Caryl Chessman, in California. Sentenced to death in 1948 for a number of kidnappings and sexual assaults, Chessman's fame grew nationally and internationally as he both loudly protested his innocence and wrote numerous essays and four books, including the best-selling Cell 2455, Death Row (1954). ${ }^{52}$ The effect of that book, as Theodore Hamm has argued in an excellent history of that case, was to transform Chessman into "the very embodiment of the postwar rehabilitative ideal." ${ }^{, 53}$ In 1960, after 12 years on death row (the longest any prisoner had spent on death row in American history) and numerous appeals and stays of execution, Chessman was executed, by means of the gas chamber. The Nation expressed a common liberal reaction: "The Chessman killed by the state was not the Chessman who committed the crime." ${ }^{54}$ His execution, like that of Sacco and Vanzetti in Massachusetts 33 years prior, galvanized public opinion around the world and generated controversy in the United States, with a major difference: this time, in contrast to 1927 , the death penalty itself was on trial.

${ }^{51}$ Truman Capote, In Cold Blood (New York: Random House, 1966)

${ }^{52}$ Caryl Chessman, Cell 2455, Death Row (New York: Prentice-Hall, 1954)

${ }^{53}$ Theodore Hamm, Rebel and a Cause: Caryl Chessman and the Politics of the Death Penalty in Postwar California, 1948-1974 (Berkeley, CA: University of California Press, 2001), 85

54 “The Value of Chessman”, The Nation, 14 May 1960, 414. Quoted in Hamm, 35 
Chessman's execution, in tandem with the other high-profile cases of the era, took place as abolitionist sentiment began to approach its peak, and some observers (as Steiker reminds us) expected the Supreme Court to put an end to capital punishment. The rehabilitative model made its way from scholarly journals to Hollywood films such as 1962's Birdman of Alcatraz (about the convicted murderer Robert F. Stroud, who after 43 years spent mostly in solitary confinement became an expert ornithologist) to top policymaking circles. In 1967, retiring Attorney General Nicholas Katzenbach published a report (The Challenge of Crime in a Free Society) that advocated for probation and parole at the expense of harsh punishment, and expressed a skeptical view of capital punishment. ${ }^{55}$ Katzenbach's successor, Ramsey Clark, went further: in Crime in America (1970), published the year after he left his post, Clark argued that the roots of crime were "deprivation and social neglect, aggravated by the dislocations of modern urban life." The social and political response to crime, he argued, should be the creation of a network of support and guidance to address crime at its roots. Regarding the death penalty specifically, Clark believed that "a humane and generous concern for every individual, for his safety, his health and his fulfillment, will do more to soothe the savage heart than the fear of state-inflicted death, which chiefly serves to remind us how close we remain to the jungle... our greatest need is reverence for life-mere life, all life-life as an end in itself."

\footnotetext{
${ }^{55}$ Nicholas Katzenbach et al, The Challenge of Crime in a Free Society: A Report by the President's Commission on Law Enforcement and Administration of Justice (Washington, DC: United States
} Government Printing Office, 1967)

\footnotetext{
${ }^{56}$ Ramsey Clark, Crime in America: Observations on its Nature, Causes, Prevention, and Control (New York: Simon \& Schuster, 1970), 337. Quoted in Hammel, 201
} 
The rehabilitative ideology, driven by and coupled with the lowering of crime rates, brought to the death penalty to its lowest point in all of American history. But by the late 1960s, at the same time that liberal elites thought they had the end of capital punishment in their sights, the rehabilitative ideal had come under sustained attack. As Hamm explains, the initial backlash to rehabilitation came from both right and left. Conservatives, on the ascendancy with the 1968 election of Richard Nixon, saw the rehabilitative model-and the liberalization of criminal justice policies generally-as lenient on criminals, failing to deter rising crime, and plain immoral, in that violent criminals would not be punished severely enough. This was part of a larger-scale conservative response (the topic of a rich scholarship) to the violent events of the late 1960s and the civil rights achievements and more radical political phenomena of the decade. ${ }^{57}$ The rise in crime rates (much of which had to do not merely with changing social conditions but also with the far more repressive state and federal criminalization policies in the era of Nixon's presidency) helped to turn the tide definitively against rehabilitation. Ironically, the ten years between 1968 and 1977 in which there was not a single execution in the United States (and in the

\footnotetext{
${ }^{57}$ For the 1960s and post-1960s conservative backlash see, e.g., Bruce J. Schulman and Julian Zelizer,
} Rightward Bound: Making America Conservative in the 1970s (Cambridge, Mass.: Harvard University Press, 2008); Rick Perlstein, Nixonland: The Rise of a President and the Fracturing of America (New York: Scribner, 2008); Laura Gifford and Daniel K. Williams, eds., The Right Side of the Sixties: Reexamining Conservatism's Decade of Transformation (New York: Palgrave Macmillan, 2012) 
midst of which the Supreme Court put a moratorium on executions) would see a remarkable growth of public and political support for keeping, and expanding, the death penalty. ${ }^{58}$

By the time the Supreme Court made its most significant intervention in the history of its constitutional oversight of capital punishment, that backlash was at its height. Furman brought to a head a clash between the abolitionist campaigns born out of the civil rights struggles of the 1950s and 1960s and the new wave of tough-on-crime conservative politics. In the short term, with Furman, the anti-death penalty legal activists won; in the long term, the hardliners had the

\footnotetext{
${ }^{58}$ Liberal rehabilitationists were not popular with the radical left of the late 1960s, either. In particular, black radicals accused them of being racially discriminatory (by highlighting the plight of white death row inmates) and of rewarding those prisoners who were most compliant with the authorities. Black Panther leader Eldridge Cleaver (a former prisoner) was one of a number of black militants who saw American prisons as inherently oppressive of poor and especially black people, and saw "reform" as a sham that was meant to protect the establishment. According to the black communist intellectual Angela Davis, "the practice of rehabilitation reinforced the racism of the criminal justice system." Interventions like these were especially significant because part of the 1950s and 1960s push against capital punishment-and harsh punishment in the justice system generally-came from the NAACP (National Association for the Advancement of Colored People) as part of a longer struggle against racial discrimination. They thus reflected a struggle within the African American community between the civil rights mainstream as represented by the NAACP and a more militant approach to racial politics as advocated by such people as Davis and Cleaver. See Angela Davis, "Political Prisoners, Prisons, and Black Liberation", in Davis, ed., If They Come in the Morning: Voices of Resistance (New York: Third Press, 1971), 37. This was her preface to her collection of essays by prisoners, several of them of the black and Latino radical left. See also Eldridge Cleaver, Soul on Ice (New York: McGraw-Hill, 1967)
} 
last say. In the context of criminal justice, the death penalty's return after Gregg has been part of what Meranze has described as the intensification of "the most punitive elements in the state and federal penal systems." ${ }^{, 59}$

The Furman verdict has been treated as a watershed moment in the history of the death penalty, and in some ways it was. There was, to begin with, the precedent of Constitutional overriding of the institution, and some of the language in the verdict-in particular, the notion that executions violated our "evolving standards of decency"-implied that the death penalty was wrong in principle. It also meant that the Supreme Court was willing, at least for a period, to consider abolition. But scholars should also be wary of exaggerating Furman's significance. Looked at in context, it appears to be another point in the long trajectory of the failure of abolition in the United States.

The Furman decision-as well as the Gregg decision, four years later-can best be understood as the culmination of the rehabilitationist era of the 1950s and 1960s, which left two important legacies in regards to capital punishment. The first was the focus on death row inmates of a particular kind-those who transformed themselves in prison, who demonstrated their humanity, and showed an aptitude for conforming to societal expectations-and, in some cases, who protested their innocence. The second was the shift to a legalized strategy for abolition, focusing in particular on race. Encouraged by the dominance of liberal courts in the pre-Nixon era, anti-death penalty campaigners-such groups as the NAACP's Legal Defense Fund and the American Civil Liberties Union (ACLU)-concentrated on trying to end capital punishment through the courts rather than through politics. This was perhaps the missed abolitionist

\footnotetext{
${ }^{59}$ Meranze, 191. For background, see the special issue on "Historians and the Careceral State", Journal of American History 102:1 (June 2015), 18-140
} 
opportunity of the era. As Hamm put it, "the arguments of racial and class discrimination made by lawyers were not linked to a broader popular movement to end the death penalty." ${ }^{\circ 60}$ In many ways, this legacy lives on: the ongoing attempts to end capital punishment by legal and not political means are rooted in a liberal belief in the Court as the nation's primary vehicle for social progress.

It is worth examining the nature of the Court's intervention in both Furman and Gregg. The Legal Defense Fund's arguments before the Court were strictly procedural: juries in capital cases followed different procedures and rules, which meant that the death penalty was applied randomly. As Stuart Banner explains, "Randomness became in effect a code word for discrimination. ${ }^{, 61}$ African-Americans, as the NAACP lawyers easily demonstrated, were being sentenced to death with greater and in higher numbers than whites. This constituted "cruel and unusual" punishment, outlawed by the Eighth Amendment. The Supreme Court accepted this line of argument, but its implication was that the institution of the death penalty could be fixedthe randomness eradicated or at least reduced, the racial discrimination stopped, juries more clearly instructed. There was nothing normative or principled about these arguments-although two of the Justices, Thurgood Marshall and William J. Brennan already believed that the death penalty was unconstitutional because it violated "evolving standards of decency", the morality

${ }^{60}$ Hamm, 152. On the LDF's approach see also Eric Muller, “The Legal Defense Fund's Capital Punishment Campaign: The Distorting Influence of Death", Yale Law and Policy Review 4:1 (Fall-Winter 1985), 158-187

${ }^{61}$ Banner, 265 
and ultimate desirability of capital punishment as an institution never really came up or was discussed by the Court. The debate was over how the death penalty could work in the future. ${ }^{62}$

Banner, Steiker, David Oshinsky, and other scholars have shown how effectively the backlash to Furman worked. In a sense, the decision came a decade late-the change in public opinion against the death penalty in the 1950 s and 1960s had created the circumstances that boosted efforts to combat capital punishment, and certainly it was no accident that the Court's decision came at a time when no executions were taking place anyway; but the legal efforts of the NAACP and the ACLU made their way to the Court's docket at a time when the public had once again swung to a strong support of execution, and states immediately took steps to rectify the statutes in order to meet the standards issued by the Court. As mentioned, the President himself weighed in, voicing his displeasure with the Furman ruling and asking Congress to find ways to bring it back for certain cases. ${ }^{63}$ By 1976 , the Court was satisfied that the death penalty was no longer overly "random" and it was, once again, Constitutionally approved, in the 7-2 Gregg decision-which, like Furman before it, revolved around procedural issues. ${ }^{64}$

\footnotetext{
${ }^{62}$ On Furman v. Georgia specifically see, e.g., Banner, 231-266, David M. Oshinsky, Capital Punishment on Trial: Furman v. Georgia and the Death Penalty in Modern America (Lawrence, Ka.: University Press of Kansas, 2010), Garland, Peculiar Institution, 206-230

${ }^{63}$ See note 25

${ }^{64}$ Much of the literature that deals with Furman connects it directly (and justly) to Gregg; see, e.g., the narrative overview by Evan Mandery, A Wild Justice: The Death and Resurrection of Capital Punishment in America (New York: Norton, 2013)
} 
France's path to abolishing the death penalty can serve as a compelling case for the “contingency" argument. As James Donovan and Robert Nye have separately shown, before the 1970s, the last time that capital punishment came up for serious national debate was in 1908, with a sustained but ultimately failed attempt at national abolition. ${ }^{65}$ By the 1960 s, capital punishment in France had dwindled to a few cases. In practice, it had nearly died out, as seemed to be the case in the United States at roughly the same time-though it is worth noting that during the ten years in which no single execution took place in the United States, seven people were guillotined in France. ${ }^{66}$

But, as Hammel explains, “dwindling public support for capital punishment... did not end in its final renunciation, only in its increasingly sparing use."67 As in the United States, abolitionists in France did not wait for the death penalty to simply peter out on its own, but

${ }^{65}$ James Donovan, "Public Opinion and the French Capital Punishment Debate of 1908”, Law and History Review 32:3 (Augist 2014), 575-609; Robert Nye, “Two Capital Punishment Debates in France: 1908 and 1981”, Historical Reflections/Reflexions Historiques, op. cit., 211-229. See also Julie Le Quang Sang, "L’abolition de la peine de mort en France: Le rendez-vous manqué de 1906-1908”, Crime, Histoire, \& Sociétés 6:1 (2002), 57-83

${ }^{66}$ Devienne, 10

${ }^{67}$ Hammel, 135 
wanted to end it once and for all. The main difference in this respect, however, was that whereas as of the 1960s American abolitionists worked through legal channels and the courts, culminating in Furman, French abolitionists chose a political path. There was a public face to the abolitionist camp in France that its American equivalent never quite had. Specifically, according to Hammel, one person made the difference. In a situation in which the death penalty was still on the books but very rarely used, "Abolition... was not going to be propelled to the center stage of French political discourse on its own; it would have to be pushed there by someone...that someone was Robert Badinter., 68

As a legal advocate for death row candidates in France in the 1970s, Badinter led the charge against capital punishment in media and political circles, earning the nickname "Monsieur Abolition". His reputation was cemented when-in a case not unlike Clarence Darrow's representation of Leopold and Loeb in the 1920s-he convinced a jury to spare his most notorious client, child murderer Patrick Henry, from the guillotine. Badinter's original approach in his abolitionist campaigns was to speak at public events. But public opinion was not in his favor. In France, as in the United States, the relatively low crime rates of the 1960s gave way to a rise in crime in the 1970s, and subsequently to a growing support for harsher punishments, especially in murder cases. Much of the popular media took a pro-death penalty position. In 1976, the singer Michel Sardou had a hit with “Je Suis Pour"-a pro-execution revenge fantasy told from the point of view of a father whose child had been raped and killed. One of the national bestsellers of 1977 was Jean Toulat's La Peine de Mort en Question, an attack on the abolition campaigns that was dedicated to murderer Patrick Henry's young victim. The book was promoted by the Association for the Defense of Children and the Application of the Death

\footnotetext{
${ }^{68}$ Ibid.
} 
Penalty (later the National League Against Crime), which argued that the French criminal justice system was weak and prisons were not sufficient punishment for murderers, and therefore keeping the death penalty-indeed, increasing its use significantly-was both a social and moral imperative. $^{69}$

Finding the public reception to his speeches increasingly hostile, Badinter switched tactics, working instead to convince his friend Francois Mitterrand, leader of the Socialist Party and close loser of the Presidential election of 1974, of the need to abolish capital punishment. In doing so, he found what would turn out to be the most effective track for promoting the abolitionist cause--one that was never really adopted in the United States.

Badinter, to be sure, did not operate in a vacuum. He was part of an elite left-wing milieu-in the legal world, politics, and the media-that adopted abolition as a cause. In an illuminating study, Elsa Devienne has shown that these abolitionists from the elite were inspired, perhaps surprisingly, by the Furman decision in the United States. Misunderstanding, in a sense, the largely procedural nature of the U.S. Supreme Court's reasoning, these elites saw the Court's decision as a principled and normative rejection of the death penalty and extolled what they supposed was the Americans' ability to see the light and turn definitively against an immoral institution. In complete opposition to how we might view the transatlantic divide over the death penalty today, in the mid-1970s the Americans (at least in the eyes of some of these French elites) were the ones who had discovered progress, and the French nation was the one clinging to the state's right to kill individuals. Ironically, at the same time that the United States was

${ }^{69}$ Jean Toulat, La Peine de Mort en Question (Paris: Pygmalion, 1977) 
experiencing a backlash to Furman, its example pushed France to move to abolition of its own death penalty. ${ }^{70}$

One crucial difference between the 1970s struggles over the death penalty in France and the United States is that debate in France took place against the backdrop of death row inmates who were the opposite, in crucial ways, of the individuals who featured heavily in the American debate. In France, the issue was presented on both sides as a stark choice: what to do with the "worst" criminals. These people's innocence was never in doubt. Their crimes were horrifying. They were reprehensible, unlikeable, and unrepentant. They were not "rehabilitated". They did not improve in prison, wrote no books, and made no other contribution to society. They had not been the victims of racial discrimination or flawed trials. When the French finally had their showdown over the future of capital punishment, later than many of their Western European counterparts and even after the Americans, they did so while facing the issue of criminals without redeeming qualities. That meant that the French debate was not procedural or within the parameters of criminal justice policy. It did not take into account the sources of crime or the degree of evil in separate acts of murder. Rather, it revolved around the principles of life and death and the state's right to kill. In the United States, abolition campaigns since the 1960s have

\footnotetext{
${ }^{70}$ Elsa Devienne, “Comparing Exceptionalism in France and the USA: A Transatlantic Approach to the
} Death Penalty Abolition Debate (1972-1977)”, European Journal of American Studies (online) 5:1 (2010, http://ejas.revues.org/7745). See also Christian Delporte, “De l'affaire Philippe Bertrand à l'affaire Patrick Henry: Un fait-divers dans l'engrenage médiatique", Vingtième Siècle. Revue d'histoire 58 (AprilJune 1998), 127-143 
been about everything except unquestionably guilty people and their heinous crimes-though these have been the trump cards used by proponents of capital punishment.

In the end, abolition in France was a political decision, the result of contingent factors-a matter of the left coming to power and pushing the issue forward even though it appeared like a political liability. There was nothing pragmatic about it, and it did not take into account ancillary issues related to criminal justice. And from a practical abolitionist standpoint, there was no need for it-the guillotine was hardly ever used and Mitterrand's predecessor had already commuted death sentences. But nor was it an event preordained in the Enlightenment or the fruit of "French values", as the abolition has been seen retrospectively. Abolition did not happen simply as a result of natural progress. Indeed, it ignored public opinion and, some might argue, the democratic will of the French people. Nye has called it, not without justification, "a coup d'état by a political and intellectual elite against the clearly established sentiments of the vast majority of the public., 71

In the run up to the 1981 election (in which he ran for the second time against the conservative Valéry Giscard d'Estaing) Mitterrand, at Badinter's urging, promised in a televised speech that he would abolish capital punishment if elected: "In my innermost conscience... in my heart of hearts, I am opposed to the death penalty." 72 This was a gamble on Mitterrand's part

\footnotetext{
${ }^{71}$ Robert Nye, 226
}

${ }^{72}$ Hammel, 141. Quote is from Sangmin Bae, When the State no Longer Kills: International Human Rights Norms and Abolition of Capital Punishment (Albany, NY: State University of New York Press, 2007), 105 
because he had nothing to gain and much to lose from taking this position before the election, but he had calculated that this would make it easier to push through abolitionist legislature once he was president. The gamble worked; but even after Mitterrand's election, abolition was not a foregone conclusion. Rather, it slipped in through a window of opportunity. Mitterrand appointed Badinter to the post of Minister of Justice (only because the previous appointee, Maurice Faure, stepped down). Mitterrand's newly ruling Socialist Party could only maintain discipline on the issue for a few months: in 1981, there was a growing resistance to the death penalty abolition, coming especially from juries, who-perhaps in anticipation and preemptive defiance of a legislative move on the issue-were suddenly handing down more death sentences than before. The government thus had to move fast, before these sentences could be finalized, in which case Mitterrand would likely commute sentences himself and risk losing public approval.

The entire process of voting over abolition took place over two months-August and September 1981. From the start, the government framed it as an issue of principle. Badinter wanted the vote (which he expected Mitterrand to win) to have "symbolic", world-historical, irreversible force, labeling it a "vote of conscience". It was separated from other matters of criminal justice policy-there was no discussion, for example, of alternatives to executions. On September 17, 1981 the Assemblée Nationale voted 333 in favor of abolition, 117 against, and 6 abstentions. Then, the Senate voted 160 for and 126 against. $^{73}$

The recordings of the proceedings in the Assemblée are, in retrospect, a stunning display of dissonance between the assigned meaning of abolition and the actual process by which it passed. ${ }^{74}$ Part of our still-misleading narrative of abolition in France (that it was the result of

\footnotetext{
${ }^{73}$ Hammel, ibid.
} 
long-term cultural processes, a European aversion to violent punishment, the supposedly deep roots of human rights) is due to the fact that the most visible recent source for understanding French abolition was written by the man most responsible for that abolition-Badinter himself. Enlightenment values and world-historical progress notwithstanding, the process of French abolition was contingent on the actions of a select few elites from the political left. And the permanence of abolition in France was not guaranteed by deep values in French society supposedly missing from the American public. ${ }^{75}$ Rather, the possible return of the death penalty was foreclosed thanks to the supranational legal-political process of European integration. In April 1983, less than two years after the French vote, France signed Additional Protocol 6 (banning the death penalty in civil cases) to the European Convention on Human Rights; next, in May 1985 the Conseil Contitutionnel (a Supreme Tribunal for constitutional questions, created by the Constitution of the Fifth Republic) adjudicated that this signature was compatible with French constitutional law. Because Article 55 of the French Constitution decrees that international treaties override acts of parliament, French lawmakers could potentially "denounce" Protocol 6, but could only break with it if they were willing to renounce the

${ }^{74}$ The 4-CD collection La peine de mort: Débats historiques à l'Assemblée Nationale en Septembre 1981 (Frémeaux \& Associés) is an extraordinary audio document.

${ }^{75}$ Robert Badinter, Abolition: One Man's Battle Against the Death Penalty (Boston: Northeastern University Press, 2008; originally published as L'Abolition, Paris: Fayard, 2000). See also Monique Y. Crochet, "Robert Badinter et L'abolition de la peine de mort", Contemporary French Civilization 8:3 (1984), 323-38; Cécile Toqué Pichon, L'abolition de la peine de mort en France. La "loi Baidnter" (Paris: Panthéon, 2006); Sandrine Costa, la peine de mort: de Voltaire à Badinter (Paris: Flammarion, 2001) 
European Union as a whole. And so, once Protocol 6 was signed, that meant the end of the death penalty in France for good-barring the dismantling of the European Union itself. ${ }^{76}$

The French trajectory played out similarly throughout Europe and elsewhere in the world. The first transformation in policy toward the death penalty was the elimination of the death penalty from the criminal codes of specific states; French abolition in 1981 marked the completion of the process in Western Europe, and it spread eastward after the fall of the Soviet Union in 1989. The second transformation was the supranational, normative framing of capital punishment as a human rights violation. We should not, however, take for granted any connection between the rise of international human rights law and the origins of national abolitions. As David Cole has reminded us, "when most Western European countries abolished the death penalty, it was not yet considered a violation of international human rights law". ${ }^{77}$ The later European development-in which nations submitted to the political and legal authority of a supranational body guided (at least officially) by human rights law, and after which abolition is considered a requirement for meeting the standards of international human rights law-is surely a product of what Samuel Moyn described as a human rights revolution of the post-1970s years. ${ }^{78}$

${ }^{76}$ Hammel, ibid.

${ }^{77}$ David Cole, “Thirty-Five States to Go”, London Review of Books 33:5 (March 3 2011), 15-16

${ }^{78}$ Samuel Moyn, The Last Utopia: Human Rights in History (Cambridge, Mass.: Harvard University Press, 2010). For a typical formal European statement, see Council of Europe, ed., The Death Penalty: Beyond Abolition (Strasbourg: Council of Europe Publishing, 2004). See also Christine Behrmann and 
Similar dynamics could be seen outside of Europe, though not in quite the same binding way: for example, in 1990 the General Assembly of the Organization of American States adopted the American Convention on Human Rights Protocol to Abolish the Death Penalty. The effect of these sorts of supranational agreements and treaties, as Garland has argued, has been to make abolition normative, to create political and economic incentives for abolition (for example, by making it a condition of belonging to the European Union or even the Council of Europe), and to internationalize-and thus create international implications for-death penalty politics, taking them out of the domains of national and local politics. ${ }^{79}$

The French example shows that top-down political leadership was a necessary ingredient for national abolition, and that the permanence of abolition is a function of its link to human rights as binding law, enshrined in political treaties. These factors have been missing from the American process-desultory and aborted-of abolition. But why did the death penalty become a human rights issue in France and the rest of Europe and not in the United States? Why has European abolition been permanent and normative while American abolition was brief and procedural? We know that much of the difference can be found at the meeting point between public opinion, elites, and political structures. But part of the answer to these questions can be

Jon Yorke, "The European Union and the Abolition of the Death penalty", Pace University Law Review 4:1 (Fall 2013), 1-79

${ }^{79}$ Garland, "Modes of Capital Punishment", 61 
found in a comparison of abolitionist arguments and strategies in Europe and the United States, especially since the 1970 s.

The history of capital punishment abolition is not quite the same as the history of capital punishment, though they are often treated as one and the same. To be sure, though, the American anti-death penalty movement is as old as the American death penalty itself. ${ }^{80}$ Even in the colonial era but especially in the revolutionary and post-revolutionary eras there were strong voices against capital punishment. Influenced in part by such abolitionist works as Cesare Beccaria's 1764 essay On Crimes and Punishments (translated into English and published in America in the 1770s), Benjamin Rush was an outright opponent of executions. Two other Founders, Benjamin Franklin and Thomas Jefferson, expressed considerable skepticism regarding state executions, which they associated with the monarchical tyranny they had rebelled against, and which they believed were not entirely compatible with the enlightened republic they envisioned. ${ }^{81}$ (They found executions more palatable when conducted by local authorities rather than the central

${ }^{80}$ Herbert H. Haines, Against Capital Punishment: The Anti-Death Penalty Movement in America, 19721994 (New York, Oxford University Press, 1996). For early abolitionism see Louis P. Masur, Rites of Execution: Capital Punishment and the Transformation of American Culture, 1776-1865 (New York: Oxford University Press, 1989)

${ }^{81}$ Cesare Beccaria, On Crimes and Punishments (Toronto: University of Toronto Press, 2008); Benjamin Rush, Consideration on the Injustice and Impolicy of Punishing Murder by Death (Philadelphia: Carey, 1792). See Masur, 62-63; 85-86; Banner, ch. 4 ("The Origins of Opposition") 
state). Other early American abolitionists grounded their arguments against executions in a religious conception of mercy and redemption. ${ }^{82}$

Scholars identify four waves of abolitionist activity in American history. The first wave peaked in the 1830s and 1840s and was connected to the climate of reform of the Jacksonian era, with its emphasis on assistance for the poor and marginalized. Expressing their revulsion at the spectacle of executions, the main accomplishment of these activists was the eventual abolition of public hangings in several northern and eastern states. (And as we have seen, a similar gradual shift from public to private executions occurred in Europe). ${ }^{83}$

The second wave took place during the Progressive Era of the late $19^{\text {th }}$ century and was connected to the reform impulse of those years. It was primarily a localized movement, focused on activism within states, and it was more successful than the first wave had been. Ten states abolished capital punishment in this period, though the trend was quickly reversed as Progressivism faded. As Herbert Haines puts it, "the abolitionist spirit fell victim to the generally violent and nativist atmosphere surrounding World War I and the later economic reversals." 84

${ }^{82}$ Haines, 7. For background on the first wave, see also Hartnett, Executing Democracy, ch. 4 (“Enlightenment, Republicanism, and Executions, 1785-1800"); Masur, Rites of Execution, ch. 3 (“The Opposition to Capital Punishment in Post-Revolutionary America"); David Brion Davis, "The Movement to Abolish Capital Punishment in America, 1787-1861", in Davis, ed., From Homicide to Slavery: Studies in American Culture (New York: Oxford University Press, 1986), 17-40; Banner, ibid.

${ }^{83}$ Haines, ibid.; Davis, 24-40; Banner, 114-139; Friedland, ibid.

${ }^{84}$ Haines, 10; see also John F. Galliher, Gregory Ray and Brent Cook, “Abolition and Reinstatement of 
The late 1920s did see a slight uptick in activism with the creation of the American League to Abolish Capital Punishment, partly in response to the Sacco-Vanzetti executions. These abolitionists were largely unsuccessful in changing death penalty policies at the time, though in the long run, as we have seen, their influence on the movement was significant. ${ }^{85}$

The third wave was in the era I discuss above (the 1950s and 1960s), during which, as Haines points out, "the master strategy for ridding the nation of capital punishment had shifted from the legislative arena to the courts. ${ }^{, 86}$ The focus on procedure, on innocent, sympathetic, and rehabilitated victims, and most important, on legal rather than political strategies, led to the brief success of Furman. This wave was most attuned to global developments, and influenced in particular by the 1953 Royal Commission on Capital Punishment, which began the process that led to abolition in Britain. ${ }^{87}$

The fourth wave, and the main focus of Haines's study, began in the wake of the backlash to Furman, after which, as he observes, "death penalty opponents who had been tempted to celebrate the final demise of executions in this nation soon realized that their goal had

Capital Punishment during the Progressive Era and Early 20th

Century", Journal of Criminal Law and Criminology 83:3 (Autumn, 1992), 538-576

${ }^{85}$ Haines, ibid.; Banner, 223-225; Temkin, 174

${ }^{86}$ Haines, 11

${ }^{87}$ Haines, 13; Block and Hostettler, 151-5; J. B. Christoph, Capital Punishment and British Politics: The British Movement to Abolish the Death Penalty, 1945-57 (Chicago: University of Chicago Press, 1962) 
not been achieved once and for all." ${ }^{, 88}$ Post-1970s abolitionism has had a variety of tactics, but most of them were judicial; in spite of the quick overturning of Furman, abolitionists have never abandoned the Constitutional path set in the 1960s and still view the Supreme Court as the key to eventual death penalty abolition. They have pointed out, again and again, that the "randomness" and injustices that led the Court to halt capital punishment in 1972 has been even worse in the post-Furman years. ${ }^{89}$ But outside the courts, the abolitionist camp did not develop a "mass movement" to accompany its legal struggle, in the ways that the civil rights, feminist, and gayrights movements have. There were and are no major demonstrations against the death penalty, even after egregious cases of botched executions. There was and is no "radical flank" to the abolitionist movement-people who would harass or disrupt respectable society and the criminal justice system (such as we see, for example, in the case of animal-rights activists). ${ }^{90}$

In this context, one major limitation of the anti-death penalty struggle in the United States will be recognizable to political historians. American politics are strongly driven by constituencies. This can be seen, for example, in the longstanding fight against gun control legislation, in which effective lobbying and organizing by the so-called gun lobby have kept in place policies that, in the face of disturbing and ever-increasing gun violence, contradict common sense and are clearly unpopular among the general public. Conversely, the struggles for

\footnotetext{
${ }^{88}$ Haines, 14
}

${ }^{89}$ See, e.g., Lindsey S. Vann, "History Repeats Itself: The Post-Furman Return to Arbitrariness in Capital Punishment", University of Richmond Law Review 45:1 (2010), 1255-1288

${ }^{90}$ Haines, 15 
women's rights, gay rights, or minority rights all had built-in natural constituencies that have given them the political leverage and dynamism necessary for change-by creating voting blocs, lobbying elected officials, fund-raising, or even just consciousness-raising. There is no real constituency, as such, to the abolitionist movement; death row inmates cannot vote and their families have no clout, political or otherwise.

The most visible public proponents of abolition are civic activists and intellectuals-often lawyers who have worked inside the machinery of capital punishment or served as advocates for condemned prisoners-who have taken on themselves the cause of representing in both the courts and the public sphere otherwise powerless individuals. ${ }^{91}$ Yet these spokespeople for abolition, impressive as they may be, rarely if ever wield policymaking power and thus their strength can be measured only in moral-not legal or political-terms. Politicians have little incentive to support abolitionism. Without a constituency, it is difficulty to achieve change within the political system, leaving abolition activists mainly with the option of trying to effect change through the courts.

The past successes of the civil rights movement in the United States were due to the combination of grassroots activism and top-down political leadership, in tandem with judicial breakthroughs. Not only does the anti-death penalty movement in the United States lack a critical grassroots presence, it also has no political leadership that is in any way equivalent to the roles

\footnotetext{
${ }^{91}$ See, e.g., the extraordinary works by Bryan Stevenson, Just Mercy: A Story of Justice and Redemption
} (New York: Spiegel \& Grau, 2014), Scott Turow, Ultimate Punishment: A Lawyer's Reflctions on Dealing with the Death Penalty (New York: Farrar, Straus \& Giroux, 2003), and David Dow, The Autobiography of an Execution (New Yor: Twelve, 2010) 
played by Badinter and Mitterrand in France. For nearly three decades, no major national political figure in the United States has been publicly associated with the abolitionist view. No viable presidential candidate, Republican or Democrat, has dared to speak out against the death penalty, whether or not they were actually in favor of it. Indeed, ever since witnessing the fate of Dukakis's candidacy in 1988, most liberal presidential aspirants have made sure to state their support of executions-or at least refrain from expressing opposition. And the administrations of those elected to the presidency have continued to seek the death penalty in federal capital cases. ${ }^{92}$

In analyzing the role of national-level politics in any future abolition, Zimring has proposed two hypothetical models of presidential action. The first is what economists refer to as a "leading indicator", in which the President takes a "bold step" in advocating against the death penalty in the hope of shifting public perceptions and thus turning the tide of opinion against executions. The second is a "lagging indicator", in which the President follows public opinion. ${ }^{93}$ To give two examples: on the civil rights issues of the 1960s, Lyndon Johnson took a "leading indicator" approach, whereas in the same-sex marriage issue of the 2010s, Barack Obama took more of a "lagging indicator" approach. In both cases the struggles succeeded (partially); but in the absence of a natural constituency, the abolitionist cause needs a "leading indicator" approach,

92 Zimring, 187-8. There has been much more political support for abolition at the Gubernatorial level, usually on fiscal or procedural grounds. For a recent analysis, see "Death in Little Rock", The Economist Feb. 92013 (http://www.economist.com/news/united-states/21571428-politicians-national-ambitions-are-

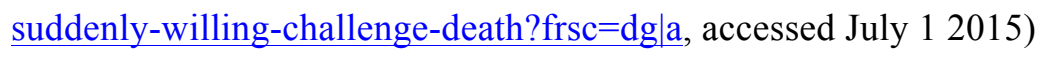

${ }^{93}$ Zimring, 191-3 
which it has not had; and in the case of recent presidents, there has not been even any sign of a "lagging indicator" approach. ${ }^{94}$

To continue the contrast with the civil rights movement: a third ingredient that turned out to be crucial for its successes was a strong geopolitical incentive. A number of scholars have shown how the Global Cold War of the 1950s and 1960s-and the accompanying propaganda battles between the United States and the communist bloc-propelled American political and legal elites to push forward civil rights legislation that might not have otherwise passed, or passed quite as fast. In other words, the internationalization of domestic struggles (as in the case of civil

${ }^{94}$ On a 2012 Presidential Race website, President Obama is quoted as follows: "I believe that the death penalty is appropriate in certain circumstances. There are extraordinarily heinous crimes, terrorism, the harm of children, in which it may be appropriate ... We have to have this ultimate sanction for certain circumstances in which the entire community says this is beyond the pale." (http://2012.presidentialcandidates.org/Obama/Capital-Punishment.php, accessed July 1 2015). President Obama restated this view in 2014 in the wake of the botched execution of Clayton Lockett in Oklahoma. See Peter Baker, “Obama Orders Policy Review on Executions”, New York Times May 2, 2014

(http://www.nytimes.com/2014/05/03/us/flawed-oklahoma-execution-deeply-troubling-obama-says.html, accessed July 1 2015). By 2015, Obama seemed to have abandoned the issue; see Matt Apuzzo, "Obama Administration Steps Back From Effort to End Federal Death Penalty”, New York Times April 29, 2015 (http://www.nytimes.com/2015/04/30/us/white-house-balks-on-ending-death-penalty.html, accessed July $12015)$ 
rights) can push the political leadership to act in a top-down fashion. ${ }^{95}$ Such global pressure on the United States that exists regarding capital punishment revolves around claims for human rights protection. Political scientist Andrew Moravcsik has pointed out that in the years before the attacks of September 11, 2001 and the ensuing "War on Terror", which changed the dynamics of America's international relations, capital punishment was the single largest source of tension in the American-European relationship (in the 1990s, the Europeans made death penalty abolition a normative demand in the process of E.U. enlargement, while in the United States the popularity and use of the death penalty were at their peak). ${ }^{96}$

\footnotetext{
${ }^{95}$ For civil rights progress and geopolitical pressure in the Cold War era, see Mary L. Dudziak, Cold War Civil Rights: Race and the Image of American Democracy (Princeton, NJ: Princeton University Press, 2000); Thomas Borstelmann, The Cold War and the Color Line: American Race Relations in the Global Arena (Cambridge, Mass.: Harvard University Press, 2003)
}

${ }^{96}$ Andrew Moravcsik, “The New Abolitionism: Why Does the U.S. Practice the Death Penalty While
Europe Does Not?”, European Studies Newsletter 4:2 (September 2001); Sangmin Bae, "Friends Do No Let Friends Execute: The Council of Europe and the International Campaign to Abolish the Death Penalty", International Politics 45 (2008), 129-145; Mark Warren, "Death, Dissent, and Diplomacy: The U.S. Death Penalty as an Obstacle to Foreign Relations", William \& Mary Bill of Rights Journal 13:2 (2004), 309-337; Evi Girling, "European Identity and the Mission Against the Death Penalty in the United States", in Austin Sarat and Christian Boulanger, eds., The Cultural Lives of Capital Punishment: Comparative Perspectives (Stanford, CA: Stanford University Press, 2005), 147-168. For background, written at the height of the transatlantic tension, see Joseph S. Nye Jr., "The US and Europe: Continental Drift?" International Affairs 76:1 (January 2000), 51-9, and Denis Lacorne, “The Barbaric Americans”, Wilson Quarterly 25 (Spring 2001), 51-5 
But that tension, though it still exists, has subsided; the issue of the American death penalty has not been internationalized to the degree that geopolitics would be a factor toward potential abolition. There is no American equivalent to the European Union-a supranational body that would incentivize, and enforce, death penalty abolition. And successive American governments have been highly selective toward-not to say, often dismissive of or hostile tointernational treaties of various sorts, particularly those concerned with human rights and international law. Although it is a member of the Organization of American States, and thus formally committed to the Inter-American Commission on Human Rights, the United States government has categorically rejected claims that it is bound to the language in both the American Declaration of the Rights of Man or the American Convention on Human Rights that restricts or prohibits the death penalty-yet another demonstration that the persistence of capital punishment in the United States is a matter of national policy and hardly the domain of only recalcitrant southern states. ${ }^{97}$ In sum, the United States has in many ways been impervious to many of the global factors that encourage and sustain abolition.
Most scholars of the death penalty would probably agree that its abolition in the United States, should it happen, would not follow the European model. Despite the relative but clear decline since the beginning of the $21^{\text {st }}$ century in public support for the death penalty, and in the

\footnotetext{
97 “Richard J. Wilson, “The United States' Position on the Death Penalty in the Inter-American Human Rights System", Santa Clara Law Review 42:4 (2002), 1159-1190
} 
numbers of death sentences, executions, and states with the death penalty, abolitionism in the United States is still rarely framed in definitive, normative terms; and the most common expectation is that abolition would only occur via the judicial branch and not the legislative or executive branches. As Hammel puts it, "the 'pure, simple, and definitive' abolition of capital punishment envisioned by Victor Hugo in 1848 and achieved in Europe seems unthinkable in the United States." 98

Intuitively, this appears odd: why would the United States, which for many of its citizens, and people around the world, is associated with the promotion and protection of human rights, not apply commonplace human rights standards to the death penalty at home? The answer has to do with another version of so-called American exceptionalism-as Michael Ignatieff has observed, while American elites have long been concerned with human rights and their promotion in the wider world, they generally do not apply human rights to internal American issues. There are American stand-ins for human rights-the Constitution in the legal realm, civil rights in the political realm-that have been the frameworks not only for the abolitionist struggle but also for a range of causes that would be considered human rights issues practically everywhere in the world except the United States. ${ }^{99}$

\footnotetext{
${ }^{98}$ Hammel, 10. From the 1820s onward, the French writer Victor Hugo was a consistent abolitionist. See, e.g., The Last Days of a Condemned Man (London: Smith \& Co., 1840; originally published as Le
} Dernier Jour d'un condamné, Paris: Gosselin, 1829)

\footnotetext{
${ }^{99}$ Michael Ignatieff, “Introduction: American Exceptionalism and Human Rights”, in Ignatieff, ed., American Exceptionalism and Human Rights (Princeton, NJ: Princeton University Press, 2005), 1-26. This volume is a useful primer on the topic of American exceptionalism, especially, in this context,
} 
To illustrate this point in relation to capital punishment, it is worth noting Zimring's juxtaposition of two anti-death penalty pamphlets distributed by the international human rights organization Amnesty International, in 2000. The first pamphlet, released in London and meant for a European and global audience, framed the death penalty in terms of human rights and the dignity of life. The second pamphlet, published in New York and addressed primarily to an American audience, made no such mentions-instead, it made an argument about the possibility of executing innocent people, along with the fiscal costs of keeping inmates on death row rather than in life imprisonment. ${ }^{100}$ This is a concrete example of how the rationale for abolition is conceived and presented differently in the United States in Europe-sometimes even by the same activists. The language used has direct policy implications, both for strategy and goals; in this case, Amnesty International made the assumption, not without reason, that human rights arguments are effective in Europe in a way that they could never be in the United States. It is in any case telling that a major human rights organization staked its claims against the American death penalty in terms that had nothing to do with human rights. ${ }^{101}$

Steiker, “Capital Punishment and American Exceptionalism”, op. cit., and Harold Honju Koh, “America’s Jekyll-and-Hyde Exceptionalism” (111-144). See also Koh, "Paying 'Decent Respect' to World Opinion on the Death Penalty", U.C. Davis Law Review 35:5 (June 2002), 1087-1131

${ }^{100}$ Zimring, 47

${ }^{101}$ For a more skeptical view of human rights as a strategy for global abolition, see David Kennedy, “The International Human Rights Movement: Part of the Problem?”, Harvard Human Rights Journal 15 (Spring 2002), 101-126 
American political leaders (as well as legal experts and abolitionists themselves, not to mention proponents of the death penalty) have thus far failed to establish a connection between death penalty abolition in the United States and human rights protection. The origins of the difference between the persistence of the death penalty in the United States versus its abolition in Europe is thus rooted in the broader difference between the American and European human rights "packages" of the 1970s and beyond. The first was produced and designed strictly for world export, the second for world export and domestic consumption; the issue of the death penalty escaped the first, but was included-and prominently featured-in the second. On the broader connection between the death penalty and the history of human rights much more scholarly work is needed.

In the end, the crucial difference at hand might not be between European and American abolitionism, but rather between abolitionism and something else-we might call it reformism. The majority of arguments brought forth by anti-death penalty campaigners in the years since Furman and Gregg have revolved around the death penalty's lack of fairness, its brutality, its incompetence, its racism, its high cost, and its ineffectiveness. (One of the most dominant debates has been over whether or not capital punishment actually deters violent crime. ${ }^{102}$ ) DNA

102 The more interesting discussion is whether a deterrent effect (if indeed it exists) justifies keeping the death penalty. See the debate sparked by Cass R. Sunstein and Adrian Vermeule, "Is Capital Punishment Morally Required? Acts, Omissions, and Life-Life Tradeoffs", Stanford Law Review 58:3 (December 2005), 703-750, which made the moral and legal case for the death penalty on the basis of its deterrent effect, and the strong critique in the same issue by Carol Steiker, "No, Capital Punishment is not Required", ibid., op. cit. See also Sunstein and Vermeule's response to that critique: "Deterring Murder: A Reply”, ibid., 847-857 
science has been the abolitionists' weapon of choice, as many of them see the innocence question as perhaps the death penalty's weakest point in public opinion as well as in legal procedure. ${ }^{103}$ These are also the aspects of capital punishment that the parts of the media most hostile to it frequently focus on. ${ }^{104}$ In recent years, many abolitionists (including scholars) have become optimistic (sometimes cautiously and sometimes bullishly) regarding the prospects for abolition. ${ }^{105}$

${ }^{103}$ See Frank Baumgartner, Suzanna L. De Boef, and Amber E. Boydstun, The Decline of the Death Penalty and the Discovery of Innocence (New York: Cambridge University Press, 2008)

${ }^{104}$ See for example the forum "What it Means if the Death Penalty is Dying", New York Times April 6 2014 (http://www.nytimes.com/roomfordebate/2014/04/06/what-it-means-if-the-death-penalty-isdying?hp\&rref=opinion, accessed July 1 2015). One of the most consistent liberal voices for abolition has been the New Yorker, most of whose excellent journalism on the death penalty revolves around innocence, race, and methods. See, e.g., Jeffrey Toobin, “Cruel and Unusual”, Dec. 232013 (http://www.newyorker.com/magazine/2013/12/23/cruel-and-unusual, accessed July 1 2015); Rachel Aviv, “Revenge Killing”, July 62015 (http://www.newyorker.com/magazine/2015/07/06/revenge-killing, accessed July 1 2015); Amy davidson, “The Death Penalty Fails Again”, July 242014 (http://www.newyorker.com/news/amy-davidson/death-penalty-fails, accessed July 2015); David Grann, “Trial by Fire”, Sep. 72009 (http://www.newyorker.com/magazine/2009/09/07/trial-by-fire, accessed July 12015$)$

${ }^{105}$ See the essays in Austin Sarat and Jürgen Martschukat, eds., Is the Death Penalty Dying? European and American Perspectives (New York: Cambridge University Press, 2011) and in Charles Ogletree and 
And yet all these serious and justified complaints fit in with the process that the death penalty has been undergoing in the United States since the beginnings of the republic, one that leads not necessarily to permanent abolition of the institution but rather to its ongoing reform. American activists against the death penalty may well be correct when they argue that the institution has been historically shaped by racism, applied unfairly, overly expensive, conducted brutally and often incompetently, and failed to deter violent crime. But even if these arguments justify abolition of the death penalty, they are not necessarily abolitionist arguments, because they do not face the central question involved in state executions. In a similar way, anti-slavery activists of the antebellum era could not be considered abolitionists if they claimed that slavery was inefficient, randomly applied, brutal, and racially discriminatory, but neglected to mention that as a matter of principle it was immoral for one man to own another man as property.

Historians are not supposed to make predictions, but we can and do speculate about the future based on our reading of the past. The Supreme Court will likely remain the primary arena for the struggle over the future of capital punishment. The Court, and not the American people or its elected leaders, will continue to receive the lion's share of media attention concerning the issue. The Court may well decide, at some point, to curtail or even end executions in the United States. However, based on the death penalty cases it has discussed, any verdict for or against the death penalty would likely be based on procedures and methods. Much of the debate would probably revolve around the issue of states' rights, the death penalty's deterrence factor, the possible execution of innocents, and the demonstrated racial bias in sentencing. It is not at all clear how any abolitionist ruling-were it to happen-would apply to the federal government and

Austin Sarat, eds., The Road to Abolition? The Future of Capital Punishment in the United States (New York: New York University Press, 2009) 
its pursuit of the death penalty in capital cases, particularly in connection to the seemingly endless War on Terror.

Nor is it at all clear that a Court decision against the death penalty based on such egregious examples as mentally challenged death row inmates, or inmates tried as juveniles, or inmates convicted in racially biased conditions, would foreclose the possibility of yet another backlash against abolition. This would be particularly pertinent in the cases that feature clearly guilty, unrepentant criminals. Public opinion may likely continue moving toward support for abolition, and this has been a source of optimism for abolitionists; yet it is worth pointing out that, in historical perspective, there is nothing astonishing, or even new, about this development. A majority of the American public was already against the death penalty in the mid-1960s, and as of 2015 support for capital punishment remains considerably higher than it was fifty years ago. History should remind us that public opinion is fickle, especially when social and economic conditions change.

What is thus most likely to happen, given the history of the death penalty thus far, is that the Supreme Court would continue its project of Constitutional oversight, and abolitionists would continue to try to attack the death penalty at what they consider to be its weakest legal points, while waiting and hoping for continued decline in public support for capital punishment and a piecemeal state-by-state process of abolition, but without carrying their activism into the national-political arena, where it likely belongs. When viewed in a transatlantic framework, the American abolitionist movement since the 1970s (if not before) has lacked the three dimensions that made abolitionism a success in France, and in Europe generally: moral, political, and supranational. This essay takes seriously the idea that an institution such as capital punishment is shaped not only by those who maintain it, but also by the strategies and language of those who 
oppose it. The comparative history of the death penalty suggests that it is a political matter before-and after-it is a legal one. Its abolition-not just its reform-will have to happen in those terms too. 